\section{Cytotoxicity of New Calcium Aluminate Cement (EndoBinder) Containing Different Radiopacifiers}

\author{
Claudia Huck ${ }^{1}$, Hernane da Silva Barud ${ }^{2}$, Fernanda Gonçalves Basso ${ }^{3}$, Carlos \\ Alberto de Souza Costa ${ }^{3}$, Josimeri Hebling ${ }^{4}$, Lucas da Fonseca Roberti Garcia ${ }^{5}$
}

\author{
'Department of Restorative \\ Dentistry, Araraquara Dental School, \\ UNESP - Universidade Estadual \\ Paulista, Araraquara, SP, Brazil \\ ${ }^{2}$ Medical-Chemistry Laboratory \\ and Regenerative Medicine \\ (QUIMMERA), Centro Universitário de \\ Araraquara, Araraquara, SP, Brazil \\ ${ }^{3}$ Department of Physiology and \\ Pathology, Araraquara Dental School, \\ UNESP - Universidade Estadual \\ Paulista, Araraquara, SP, Brazil \\ ${ }^{4}$ Department of Orthodontics \\ and Pediatric Dentistry, \\ Araraquara Dental School, \\ UNESP - Universidade Estadual \\ Paulista, Araraquara, SP, Brazil \\ ${ }^{5}$ Department of Dentistry, Endodontics \\ Division, Health Sciences Center, \\ UFSC - Universidade Federal de Santa \\ Catarina, Florianópolis, SC, Brazil
}

Correspondence: Dr. Lucas da Fonseca Roberti Garcia, Avenida Madre Benvenuta, $\mathrm{n}^{\circ}$ 388, apto. 713, Bairro Trindade, 88036500 Florianópolis, SC, Brasil. Tel: +55-48-3721-9549/99173-0776. e-mail: drlucas.garcia@gmail.com

Key Words: cytotoxicity; cell viability; calcium aluminate cement; mineral trioxide aggregate.

\section{Introduction}

Direct pulp capping (DPC) consists of applying a protective agent over the pulp when it is exposed, preserving and maintaining the vitality and function of this specialized connective tissue (1). Studies have shown that mineral trioxide aggregate (MTA) is one of the most used capping agents for application on exposed pulps, with which new cements must be tested and compared $(2,3)$.

In spite of various studies demonstrating the biocompatibility (3) and bioactivity $(4,5)$ of MTA, bismuth oxide $\left(\mathrm{Bi}_{2} \mathrm{O}_{3}\right)$, the inorganic compound that provides radiopacity to the cement, interferes in its hydration mechanism (6), compromising calcium ions release to the tissue (7). Therefore, the formation of hard reparative tissues on exposed pulps and the formation of a complete mineralized barrier may be a negative influence of $\mathrm{Bi}_{2} \mathrm{O}_{3}$ in the MTA composition (8). Additionally, the effect of $\mathrm{Bi}_{2} \mathrm{O}_{3}$ on pulp cells has not yet been completely understood (9). Some studies demonstrated that heavy metal salts, among them bismuth and cadmium, induce the expression of the heme oxygenase-1 (HO-1) enzyme in different cell lines, like the cells of the human intestinal epithelium (DLD-1) (10) and human dental pulp cells (HDPCs) (9). This enzyme is induced by nitric oxide (NO) and by various pro-inflammatory cytokines and there is evidence that it is involved in cell's regulatory and protective functions $(9,10)$.

Materials used for DPC are clinically applied before they set, and therefore, some of their components may be diluted and then diffuse through the pulp tissue, producing undesirable side effects (11). After 60 days of direct application on the pulp tissue of human teeth, components arising from MTA with $\mathrm{Bi}_{2} \mathrm{O}_{3}$, were visualized in contact with the cytoplasm of endothelial cells and within blood vessels (11). Relevant and at the same time disconcerting scientific data such as these justify the development and constant improvement of new capping agents that must present adequate biological compatibility and bioactivity (12). Moreover, alternative radiopacifiers, such as $\mathrm{ZnO}$ and $\mathrm{ZrO}_{2}$, have been extensively studied and tested, obtaining excellent results with regard to their biological, chemical and physical-mechanical properties (13)

Therefore, a new calcium aluminate-based cement used for DPC and root perforation sealing (EndoBinder; Binderware, São Carlos, SP, Brazil - Patent Number PI0704502-6), was developed, taking advantage of the 
excellent properties of MTA, but endeavoring to eliminate its negative characteristics (6-8). The aim of this in vitro study was to evaluate - in comparison with MTA - the cytotoxicity of the calcium aluminate cement - EndoBinder - containing three different radiopacifiers $\left(\mathrm{Bi}_{2} \mathrm{O}_{3}, \mathrm{ZnO}\right.$ or $\mathrm{ZrO}_{2}$ ), when applied to MDPC-23 odontoblast morphologylike cells in culture before cement's setting time. The null hypotheses tested were: (i) there is no difference in cytotoxicity between the MTA and EndoBinder cements, and (ii) the type of radiopacifier does not interfere in the cytotoxicity of the EndoBinder cement.

\section{Materials and Methods}

\section{Preparation of Samples}

The cements used in this study, their components and manufacturers are in Table 1. All the cements were manipulated according to the manufacturers' recommendations, under aseptic conditions in a vertical laminar flow workstation (Bio Protector Plus 12; Veco do Brasil - Ind. Com. de Equipamentos Ltda, Campinas, $\mathrm{SP}$, Brazil). For the different versions of EndoBinder, the proportion of $1 \mathrm{~g}$ of powder to $0.21 \mathrm{~mL}$ distilled water was used; and for MTA, one dose of powder $(0.15 \mathrm{mg})$ to 1 drop . $(50 \mu \mathrm{L})$ distilled water. Therefore, cement samples weighing $0.2 \mathrm{~g}$ were used to perform the experiments, according to ISO 10993-12:2012 (E) recommendations (14).

\section{Cell Culture}

Immortalized odontoblast-like MDPC-23 cells were defrosted and cultivated in $75 \mathrm{~cm}^{3}$ plastic bottles (Costar Corp., Cambridge, MA, USA) in Dulbecco's Modified Eagle Medium culture (DMEM) (Gibco, Grand Island, NY, USA), containing 10\% fetal bovine serum (FBS) (Gibco), 100 $\mathrm{IU} / \mathrm{mL}$ and $100 \mu \mathrm{g} / \mathrm{mL}$ of penicillin and streptomycin, respectively, and $2 \mathrm{mmol} / \mathrm{L}$ glutamin (Gibco), kept in an incubator (Isotemp Fisher Scientific, Pittsburgh, PA, USA) in humid atmosphere containing $5 \% \mathrm{CO}_{2}, 95 \%$ air, at 37 ${ }^{\circ} \mathrm{C}$. Every $72 \mathrm{~h}$ the cells were subcultivated at a density of $3 \times 10^{4} \mathrm{cells} / \mathrm{cm}^{2}$, until obtaining an adequate number of cells to begin the experiments.

\section{Experimental Procedure}

The odontoblast-like MDPC-23 cells were seeded ( $1 \times 10^{4}$ cells/well) in sterilized 96-well plates, and stored in an incubator at $37{ }^{\circ} \mathrm{C}$, with $5 \% \mathrm{CO}_{2}$ and $95 \%$ air for $24 \mathrm{~h}$. Cement samples $(n=6)$ previously manipulated in a vertical laminar flow working station were immediately (before cement's setting) applied individually in transwell inserts with $0.4 \mu \mathrm{m}$ pores (Corning Inc., Corning, NY, USA), which in turn were placed in sterilized 24-well plates containing $1 \mathrm{~mL}$ DMEM without FBS. The number of samples for each group was determined according to previous studies that evaluated the effects of similar dental materials on dental pulp cells $(5,11)$. After $24 \mathrm{~h}, 100 \mu \mathrm{L}$ of the obtained extract (DMEM + components released from the cements) were collected and applied to the MDPC-23 cells in culture. In the negative control group, $100 \mu \mathrm{L}$ of DMEM were applied to the cells. The experiments were performed in triplicate and at different time intervals, according to the ISO 1099312:2012 (E) recommendations (14).

\section{Cell Viability Analysis}

Cell viability was analyzed by the methylthiazol tetrazolium assay (MTT Assay). This method determines the activity of the succinate dehydrogenase enzyme produced by the mitochondria of the cells (15). For this purpose, the extracts in contact with the cells for $24 \mathrm{~h}$ were aspirated and $100 \mu \mathrm{L}$ of DMEM containing 10\% MT solution ( $5 \mathrm{mg} /$ $\mathrm{mL}$ of PBS) were applied in each well. The MDPC23 cells were incubated in contact with this MTT solution for $4 \mathrm{~h}$. After this period, the solution was carefully aspirated and the formazan crystals formed by cleavage of the MTT salt (Sigma-Aldrich Corp. St. Louis, MO, USA), were solubilized in 100 $\mu L$ isopropanol acidified with $\mathrm{HCl} 0.4 \mathrm{~N}$. After agitation and verification of the homogeneity of the solutions, cell viability was evaluated

EB, EndoBinder; Bi203; bismuth oxide; ZnO, zinc oxide; ZrO2, zirconium oxide; MTA, Mineral Trioxide Aggregate; $\mathrm{Al203}$, aluminum oxide; $\mathrm{CaO}$, calcium oxide; $\mathrm{SiO2}$, silicon dioxide; MgO, magnesium oxide; Fe203, ferric oxide; CaSO4, calcium sulphate. 
proportionally to the absorbance determined at $570 \mathrm{~nm}$ in a spectrophotometer (Synergy H1 Hybrid multi-Mode Microplate Reader; Biotek Instruments, Winooski, VT, USA). The numerical data obtained were converted into percent of the control group.

\section{Total Protein Production}

Total protein production analysis was determined by the Lowry method (16). After the extracts and pure DMEM had been aspirated from all the experimental groups and control, respectively, $100 \mu \mathrm{L} 0.1 \%$ sodium lauryl phosphate, (Sigma-Aldrich Corp.) were applied in each well and the cells were incubated at room temperature for $40 \mathrm{~min}$ (50 $\mu \mathrm{L}$ of the cell lysis solution were used for analyzing ALP activity). After this, $100 \mu \mathrm{L}$ of Lowry reagent solution (Sigma-Aldrich Corp.) were added to the cells, further incubated for $20 \mathrm{~min}$. Subsequently, $50 \mu \mathrm{L}$ of Folin \& Ciocalteu's phenol reagent (Sigma-Aldrich Corp.) were added to the samples, and 40 later, the absorbance readout in the spectrophotometer (Synergy H1 Hybrid multi-Mode Microplate Reader), was made at a $590 \mathrm{~nm}$ wavelength. The total protein concentration of each sample was determined by a standard curve containing pre-determined concentrations of bovine albumin.

\section{Alkaline Phosphatase (ALP) Activity}

Alkaline phosphatase activity was determined in accordance to the Alkaline Phosphatase Kit protocol End-Point Assay (Labtest Diagnóstico S.A., Lagoa Santa, MG, Brazil) (16).

The culture medium was aspirated and $150 \mu \mathrm{L} 0.1 \%$ sodium lauryl sulphate (Sigma-Aldrich Corp.) were added to the cells in each compartment at room temperature, for $40 \mathrm{~min}$. Meanwhile, tubes containing $50 \mu \mathrm{L}$ substrate (thymol-phthalein monophosphate $22 \mathrm{mmol} / \mathrm{L}$ - reagent No. 1 of the Kit) and $500 \mu \mathrm{L}$ buffer solution $(300 \mathrm{mmol} / \mathrm{L}$, $\mathrm{pH} 10.1$ - reagent No. 2 of the Kit) were prepared, and then incubated in a double boiler at $37^{\circ} \mathrm{C}$ for $2 \mathrm{~min}$. After this, $50 \mu \mathrm{L}$ of each sample were added, and after incubation for $10 \mathrm{~min}, 2 \mathrm{~mL}$ Color Reagent (sodium carbonate $94 \mathrm{mmol} / \mathrm{L}$ and sodium hydroxide $250 \mathrm{mmol} / \mathrm{L}$ - reagent No, 3 of the Kit) were added. Aliquots of $100 \mu \mathrm{L}$ of each sample were transferred in duplicate to 96-well plates. Absorbance was determined in a spectrophotometer (Synergy H1 Hybrid multi-Mode Microplate Reader), at a $590 \mathrm{~nm}$ wavelength .

Alkaline phosphatase activity was calculated from the standard curve containing pre-defined concentrations of the enzyme (\%).

\section{Cell Morphology Analysis by Scanning Electron Microscopy (SEM)}

Two samples from each experimental group and the control group were prepared for qualitative cell morphology analysis by scanning electron microscopy (SEM) (Inspect S50, Hillsboro, OR, USA) (17). MDPC-23 cells in complete DMEM were seeded ( $5 \times 10^{4}$ cells) on sterilized glass slides, previously placed at the bottom of 24-well acrylic plates. After $24 \mathrm{~h}$ incubation, the culture medium was replaced by the extracts of the materials incubated in contact with the cells for $24 \mathrm{~h}$. After this period, the extracts were aspirated and $200 \mu \mathrm{L}$ of $2.5 \%$ glutaraldehyde fixative solution were applied to each well for $2 \mathrm{~h}$. After fixation, the cells that remained adhered to the glass slide were washed with buffered saline solution (PBS) and then post-fixed for 60 min with $200 \mu \mathrm{L}$ of $1 \%$ osmium tetroxide solution (SigmaAldrich Corp.). The samples were dehydrated by ascending ethanol solutions $(30 \%, 50 \%$ and $70 \%$, twice with $95 \%$ and twice with 100\% - 30 min in each solution) and finally submitted to drying with 1,1,1,3,3,3-hexamethyldisilazane (HMDS; Acros Organics, New Jersey, NY, USA). Immediately after being attached to metal stubs and kept in a desiccator device for $24 \mathrm{~h}$, the samples were sputter-coated with gold (Balzers Sputter Coater SCD 004; BAL-TEC AG, Balzers, Liechtenstein) and cell morphology was evaluated, in a blind manner, by a single previously calibrated observer.

\section{Chemical Analysis by Energy-Dispersive Spectroscopy} (EDS)

The extracts obtained from each tested cement or from DMEM (control) were evaluated by SEM (JEOL 7500F model, Tokyo, Japan), with a field emission source and dispersive energy spectroscopy (EDS). Analysis by EDS allowed semiquantitative detection and identification of chemical elements in the culture medium, if released by the cements (17). For this purpose, $50 \mu \mathrm{L}$ of the extract of each cement were applied to a silicon plate kept in a desiccator for $12 \mathrm{~h}$. After covering the samples with carbon, they were energized, enabling the chemical elements to be identified by means of the released radiation wavelength.

\section{Statistical Analysis}

The values obtained for the cell viability analysis, total protein production and ALP activity did not present normal distribution (Shapiro-Wilk test, $\mathrm{p}<0.05$ ). Thus, the data obtained were statistically analyzed by the nonparametric Kruskal-Wallis test, at a 5\% level of significance (GraphPad Prism 4.0; GraphPad Software, La Jolla, CA, USA). No statistical analysis was performed for EDS evaluation.

\section{Results}

\section{Cell Viability, Total Protein Production and ALP Activity \\ The results for cell viability, total protein production and ALP activity are in Figure 1.}


The extracts obtained from the tested cements caused reduction of less than 30\% in the odontoblast-like MDPC23 cells viability. According to the ISO 10993-12:2012 (E) recommendations (14), this pattern of decrease in cell viability demonstrated that the tested cements were not cytotoxic. Only cells exposed to the extracts obtained from the different versions of EndoBinder cement had a barely detectable tendency to reduce cell viability and total protein production. However, the absorbance values observed for these groups were statistically similar to NC and WMTA groups ( $p>0.05$ ). The results for ALP activity had a small decrease for EBZnO group, but there was no statistically significant difference between this groups and the other groups ( $p>0.05$ ).

\section{Cell Morphology Analysis (SEM)}

The images referring to the morphology of odontoblastlike MDPC-23 cells are in Figure 2. The photomicrographs demonstrated proliferation and adherence of MDPC-23 cells on the glass substrate in all experimental groups
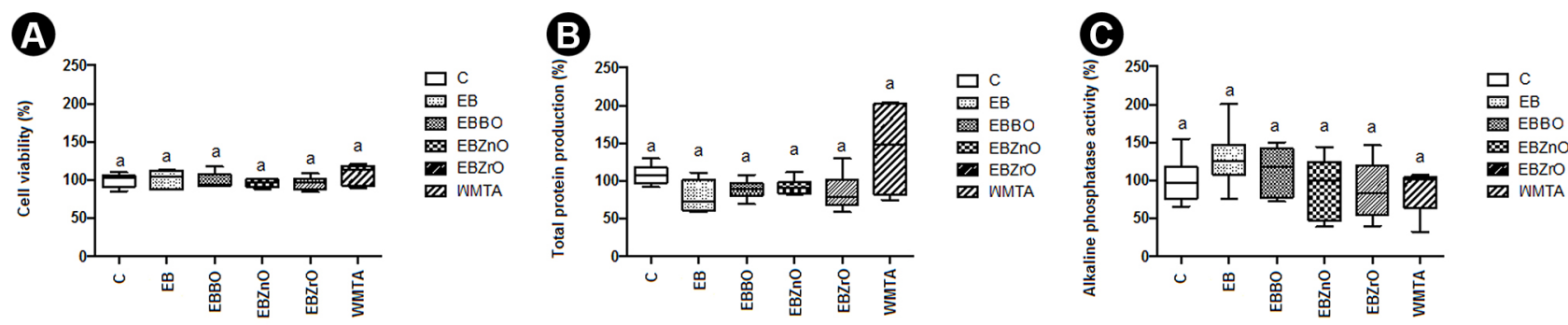

Figure 1. Graphic representation of cell viability (A); total protein production (B) and ALP activity (C), after contact of odontoblast-like MDPC23 cells with the extracts from the tested cements. The values (in percent) were calculated from the control group, considered 100\%, and are presented as median and percentiles (P25 and P75). Groups identified with equal letters showed no statistically significant difference (KruskalWallis, $\mathrm{p}<0.05) . \mathrm{n}=6$
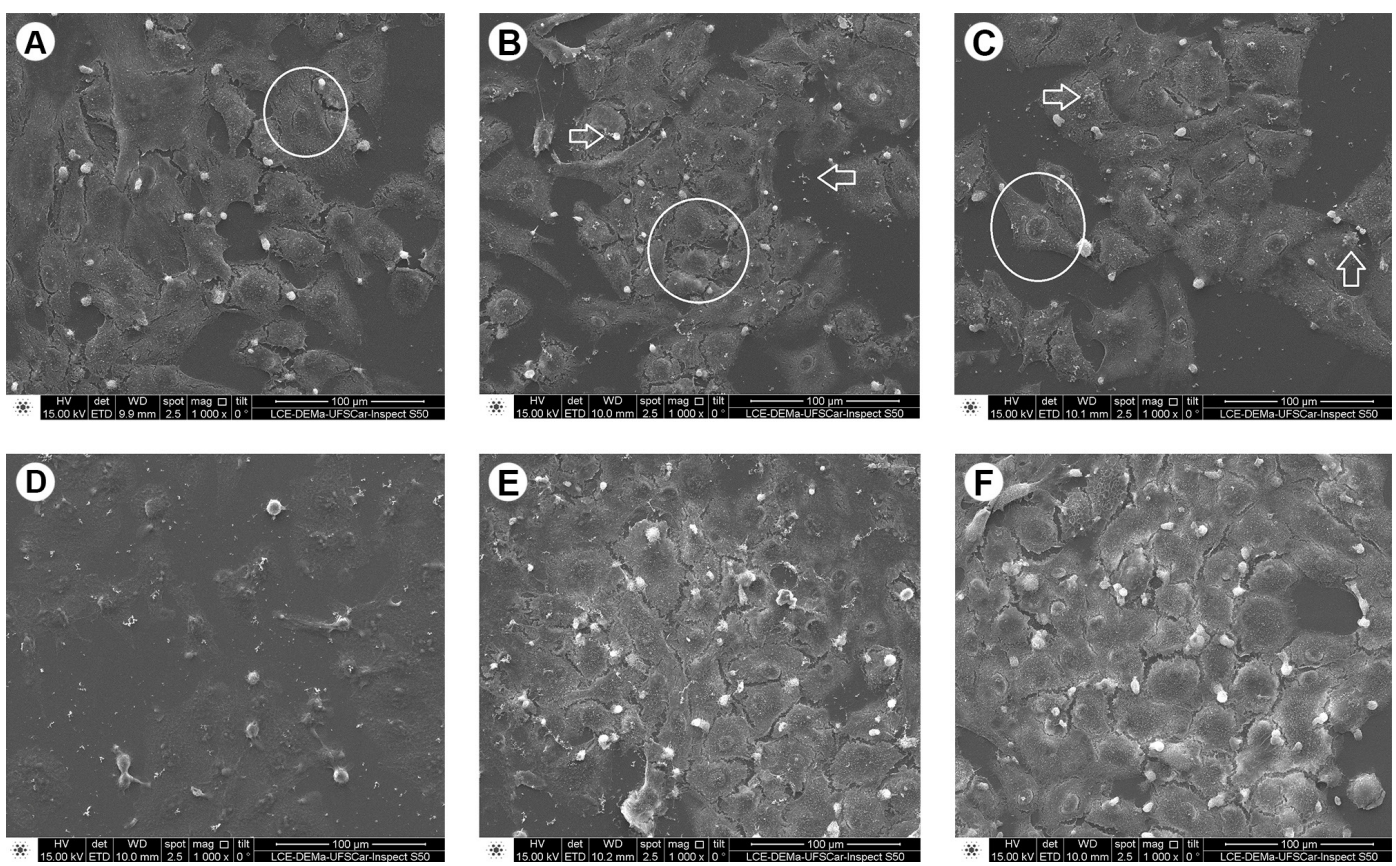

Figure 2. Representative photomicrographs of the MDPC-23 cells morphology observed by SEM; original magnification, 1000'. A: Negative Control: Large number of MDPC-23 cells with wide cytoplasm (circle), organized in epithelioid nodule, covering a large part of the glass substrate. B: EndoBinder: In the same way as observed in NC group, a large number of cells were found adhered to the glass substrate (circle). However, it was possible to observe small cement particles deposited on the glass slide and cells (arrows). C: EndoBinder+Bi203: MDPC-23 cells with normal morphology (circle), such as observed in NC group. Cement residues may be seen on the cells and substrate. D: EndoBinder+ZnO - In this group it was possible to observe cells adhered to the glass substrate. Some cells showed reduction in their normal size, due to shrinkage of the cytoplasm (arrow). E: EndoBinder+ZrO2 - Large quantity of cells with wide cytoplasm, covering almost the entire glass substrate on which they were previously cultivated. Cement residues were observed on the cells and substrate. F: White MTA - In this Group, the authors could observe findings similar to those of the other groups, in which cells with wide cytoplasm were organized in an epithelioid nodule. 
and control. Except for the EBZnO group, the cells of the groups treated with the extracts from the cements had morphological characteristics similar to the NC group, with wide cytoplasm and several short prolongations responsible for the cells' adherence to the substrate. In EBZnO group, MDPC-23 cells smaller than normal were detected. In all the experimental groups, it was also possible to observe particles of dispersed cement that passed through the 0.4 $\mu \mathrm{m}$ pores of the transwell inserts and deposited on the MDPC-23 cells adhered to the glass substrate.

\section{SEM/EDS Analysis}

The photomicrographs/spectra of the EDS analysis of the extracts from the cements are in Figure 3 . The analyses demonstrated presence of the main components of each material in the extracts. In NC group, which contained only culture medium (DMEM), the main detected elements were $\mathrm{O}, \mathrm{Na}, \mathrm{Cl}, \mathrm{K}$ and $\mathrm{Si}$, the four first components being those of the culture medium itself. Si corresponded to the silicon plate used for adding the extracts for assay. The groups containing the extracts of EndoBinder (with and without radiopacifiers) showed similarity in the detected elements ( $\mathrm{C}, \mathrm{O}, \mathrm{Na}, \mathrm{Al}, \mathrm{P}, \mathrm{S}, \mathrm{Cl}, \mathrm{K}$ and $\mathrm{Ca}$ ). However, in EBZnO group it was not possible to detect $\mathrm{Ca}$. Moreover, in the photomicrographs of the EndoBinder groups, was observed a large amount of particles that detached from the cement, passed through the transwell inserts and dispersed in the culture medium. As for the WMTA group, the elements $C$, $\mathrm{O}, \mathrm{Na}, \mathrm{Si}, \mathrm{Cl}$, and $\mathrm{K}$ were detected. Furthermore, the amount of elements dispersed in the medium was numerically lower for the WMTA group compared with the EndoBinder groups.

\section{Discussion}

The aim of this study was to evaluate the cytotoxicity of EndoBinder, a new calcium aluminate-based cement, containing different radiopacifiers, in comparison with MTA cement. Based on the obtained results, both hypotheses of the study were accepted, since the cements had similar cytotoxicity, irrespective of the radiopacifier agent included in the EndoBinder formulation.

Radiopacity in an essential property for a cement to be identified and distinguished from the adjacent anatomic structures (18). Similarly, it is stressing that is also crucial use of radiopacifiers that do not compromise biocompatibility and the physico-chemical performance of the materials (19). Therefore, versions of the calcium aluminate-based cement EndoBinder containing three different radiopacifiers $\left(\mathrm{Bi}_{2} \mathrm{O}_{3}, \mathrm{ZnO}\right.$ and $\left.\mathrm{ZrO}_{2}\right)$ were evaluated
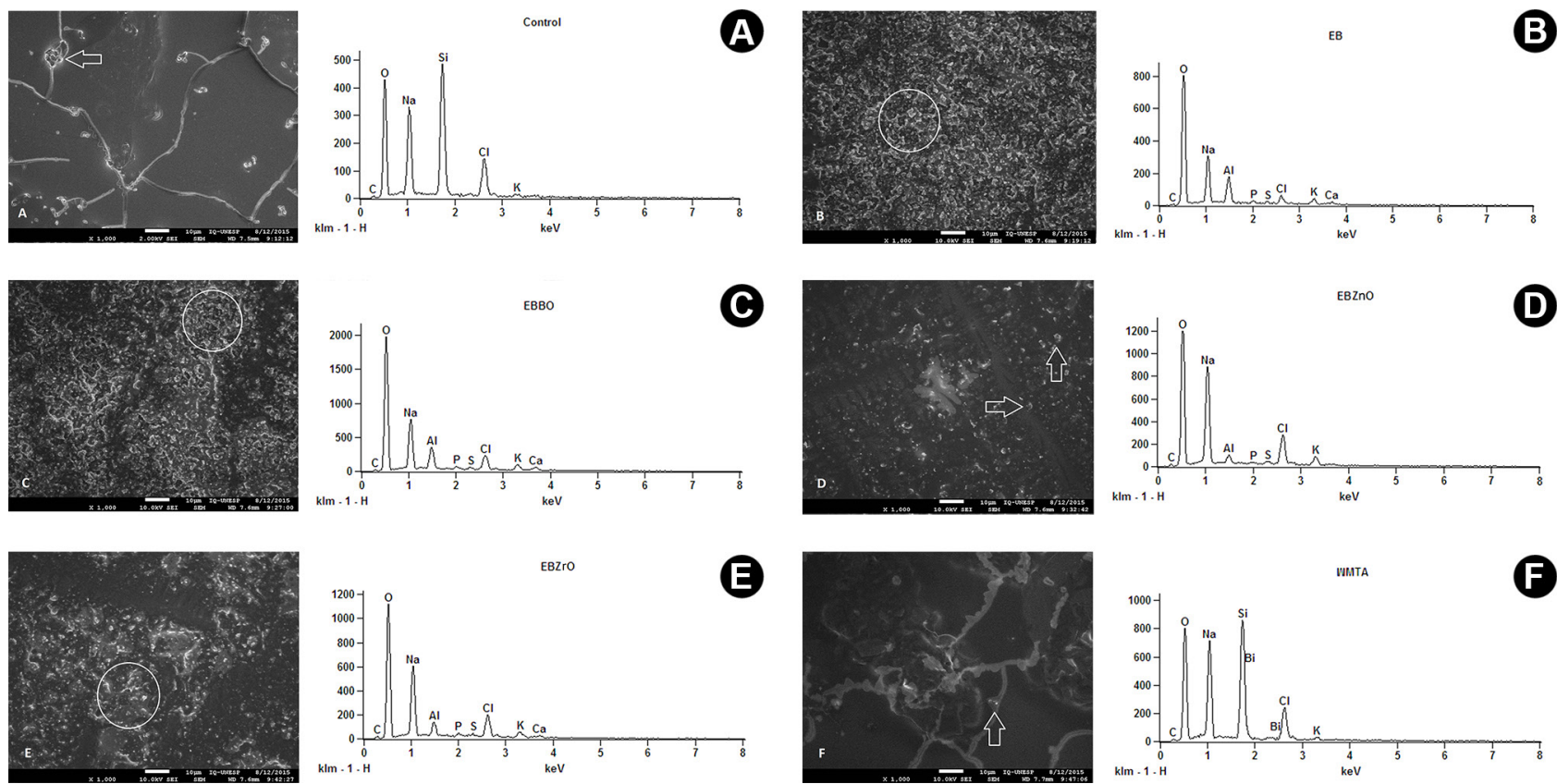

Figure 3. Photomicrographs (left) and respective graphs (right) representative of SEM/EDS analyses (original magnification, 1000') of the chemical elements in the extracts from the different tested cements. A: Negative Control: Note the presence of only some small particles (arrow) with reference to the chemical components in the culture medium (graph). B: EndoBinder - Large quantity of cement particles dispersed within the extract and deposited on the silicon substrate (circle). Main chemical elements detected in the sample (graph). C: EndoBinder+Bi203: Cement particles (circle) deposited on the silicon substrate. D: EndoBinder+ZnO: In this group, a smaller quantity of dispersed particles could be observed (arrows). In the graph, note the main chemical elements detected, but element Ca was not identified, differently from the other EndoBinder groups. E: EndoBinder+ZrO2: Cement residues (circle). Within the cement components, the authors were able to detect the presence of C, 0 , Na, Al, P, S, $\mathrm{Cl}, \mathrm{K}$ and $\mathrm{Ca}$ (graph). F: White MTA: In this group, note the small quantity of particles dispersed and deposited on the silicon substrate (arrow), in comparison with the EndoBinder groups. In the graph, note the main chemical elements detected. 
in this study. In addition to the versions containing $20 \%$ of radiopacifiers in their composition, a version of EndoBinder without radiopacifier was tested to clarify possible doubts related to the effects of these compounds on the cement cytotoxicity. Considering the radiopacity provided to the cement, $\mathrm{Bi}_{2} \mathrm{O}_{3}$ is the most efficient radiopacifier, followed by $\mathrm{ZnO}$ and $\mathrm{ZrO}_{2}$ (20).

According to the results from the present study, none of the tested cements presented cytotoxicity $(\geq 30 \%$ in comparison with the control group) higher than the one proposed by the ISO 10993-12:2012 (E) recommendations (14), thus being considered cytocompatible. Therefore, the different radiopacifiers added to EndoBinder had no influence on the biocompatibility of the material.

Previous studies reported that the rate of calcium ion release of MTA was significantly compromised due to the presence of $\mathrm{Bi}_{2} \mathrm{O}_{3}$ in its composition $(6,7)$. However, various in vivo studies that assessed the biocompatibility of this cement $(21,22)$ demonstrated that after 30 days, the material allowed adequate tissue repair, indicating that the alkaline $\mathrm{pH}$ produced by calcium ion release was maintained $(22,23)$. It is believed that this ability to maintain the alkaline $\mathrm{pH}$ of the medium is the main responsible for the excellent biological performances of MTA and EndoBinder (21).

The release of calcium ions by EndoBinder is regulated by the decomposition of hydrated calcium aluminate and this occurs at a slower speed compared with MTA (24). In spite of the slower release of calcium ions by EndoBinder, the odontoblast-like MDPC-23 cells exposed to the extracts obtained from the cement, whether they contained different radiopacifiers or not, had similar viability of cells exposed to the MTA extract, which determined the cytocompatibillity of the material.

Semi-quantitative analyses by SEM/EDS of the chemical elements released by the cements demonstrated the presence of the element $\mathrm{Ca}$ in three of the four groups containing the EndoBinder extracts, with this element being undetected in the EBZnO and WMTA groups (Figs. $3 \mathrm{~d}$ and 3f). While no Ca was detected in EBZnO group, the element $P$ (phosphorus) was identified in all the groups containing the EndoBinder extracts. The mere presence of $\mathrm{P}$ indicates the Ca presence, even though this is not detected by SEM/ EDS, due to the formation of a calcium phosphate phase in the extracts, which in turn, constituted an indicator of the material bioactivity (25). The bioactivity of a material is defined as the capacity to promote a local response when in contact with a living tissue and generate an interface chemical bond (4). In spite of the elements $\mathrm{Ca}$ and $\mathrm{P}$ being undetected in the semi-quantitative analyses of the extracts from WMTA group, probably due to a technique limitation (17), the assay for alkaline phosphatase activity confirmed the positive bioactivity for this cement.

In all the experimental groups, the authors observed presence of small-dispersed particles of the cements that were deposited on the MDPC-23 cells and glass substrate. Pores of the transwell inserts are known to be $0.4 \mu \mathrm{m}$ in diameter and that a part of the particles in the MTA powder, according to the manufacturer, have a size of approximately $0.3 \mu \mathrm{m}$. These facts may explain the passing of MTA components through the pores of the inserts and their deposition on the cells adhered to the substrate where they were cultivated. It is also worth to pointed out that some MDPC-23 cells from the EBZnO group presented reduction in their normal size (cells smaller than normal), due to shrinkage of the cytoplasm. However, such finding did not compromise the cytocompatibillity results of the material in this specific group, according to ISO 1099312:2012 (E) recommendations (14).

The sinterization process of EndoBinder, in which the cement's chemical elements undergo high temperatures, but slightly below their melting point, guarantee a more uniform composition of the material (26). Moreover, the particles undergo a chemical process that allows obtaining a powder with a more refined granulation, providing a material with superior handling characteristics than MTA $(26,27)$.

The physical characteristics of the particles of EndoBinder as well as the solubility and disintegration of the cement (28), which may exceed the limit proposed by Specification No.57 of ANSI/ADA (29), may lead to a larger quantity of the cement components passing through the pores of the inserts to reach the cells and perhaps cause irreversible damage to them. Nevertheless, in spite of the high solubility of the different versions of EndoBinder (28), the cement was not toxic to the MDPC-23 cells.

The solubilization of the cement is an important factor for its bioactivity, particularly due to the distribution of $\mathrm{Ca}$ and hydroxyl ions on the pulp tissue $(3,5,30)$. Previous studies demonstrated that the hydration process of EndoBinder and MTA accentuates the release of $\mathrm{Ca}$ and hydroxyl ions, which are the main components found in soluble and insoluble residues of these cements $(3,5,30)$, with an effective participation in the tissue repair process. Although Ca was detected in most groups by SEM/EDS analysis in the present study, Ca and hydroxyl ions were not detected. In a recent study, Pires-de-Souza et al. (24) reported that the lower values of released $\mathrm{Ca}$ and hydroxyl ions occur in the initial $48 \mathrm{~h}$ after immersion of cements (EndoBinder and MTA) in distilled water. These values increase significantly after 7 days, reaching the peak at the 28th day after immersion. In the present study, the cements remained immersed in DMEM for only $24 \mathrm{~h}$, which may explain the undetection of these ions due to their lower 
concentration in the extracts. In addition, solubilization of these cements promotes the release of several heavy metals like $\mathrm{As}, \mathrm{Cr}$ and $\mathrm{Pb}$ (28). However, in the present study, none of these heavy metals could be detected by SEM/EDS analysis, and even if they were present, they were not capable of interfering in the biological compatibility of the cements. The same could be said with regard to the radiopacifiers used in cement formulations. Only in WMTA group, it was possible to detect the presence of $\mathrm{Bi}$ in the culture medium. Particles of the radiopacifiers used in the different versions of EndoBinder were not detected by the SEM/EDS analysis, which suggests an interaction between the cement and radiopacifiers, since they were not released into the medium, at least in the first $24 \mathrm{~h}$ (19).

According to the methodology used in this study, EndoBinder containing different radiopacifiers may be considered cytocompatible, likewise the MTA cement. In the SEM analysis, some cells from the EBZnO group were smaller than normal ones, but this version of EndoBinder was considered cytocompatible, according to the other tests performed in this study. The clinical significance should be viewed favorably, as MTA has been considered the gold standard for many years due to its adequate biological compatibility and bioactivity. Thus, EndoBinder brings a promising option for pulp capping therapy.

However, it should be underscored that the results of these initial in vitro cytotoxicity tests present limitations, and as it has been previously stressed in the literature (11), they must not be extrapolated directly to clinical situations. Therefore, further in vivo researches using this new calcium aluminate-based cement are required to demonstrate its biological properties when applied to exposed pulp tissue.

\section{Resumo}

Este estudo avaliou a citotoxicidade de um cimento de aluminato de cálcio (EndoBinder) contendo diferentes radiopacificadores, $\mathrm{Bi}_{2} \mathrm{O}_{3}, \mathrm{ZnO}$ ou $\mathrm{ZrO}_{2}$, comparativamente ao trióxido mineral agregado (MTA). Seguindo a norma ISO 10993-12:2012 (E), 0,2 g de cada cimento foi aplicada em insertos transwell, que foram colocados em placas de cultura de 24 wells contendo $1 \mathrm{~mL}$ de meio de cultura (DMEM). Após $24 \mathrm{~h}$ de incubação, os extratos (DMEM contendo componentes liberados dos cimentos) foram aplicados sobre células pulpares imortalizadas MDPC-23. Viabilidade celular (teste de MTT), atividade da fosfatase alcalina (ALP), produção de proteina total e a morfologia das células (Microscópio Eletrônico de Varredura - MEV) foram avaliadas. Um volume de $50 \mu \mathrm{L}$ do extrato foi utilizado para determinar, através de Espectroscopia de Energia Dispersiva (EDS), os elementos quimicos liberados pelos cimentos. Os seguintes grupos foram estabelecidos $(n=6)$ : NC - controle negativo (sem tratamento); $E B$ - EndoBinder sem radiopacificador; $\mathrm{EBBO}$ - EndoBinder $+\mathrm{Bi}_{2} \mathrm{O}_{3} ; \mathrm{EBZnO}$ EndoBinder+ZnO; EBZrO - EndoBinder $+\mathrm{ZrO}_{2}$ e WMTA - MTA branco. Os dados foram submetidos à análise estatística (teste de Kruskal-Wallis, nivel de significância $=5 \%$ ). Células expostas às diferentes versões de EndoBinder apresentaram pequena redução na viabilidade, produção de proteina total e atividade da ALP, com valores semelhantes aos grupos NC e WMTA $(p>0,05)$. Diversos elementos $(C, 0, N a, A l, P, S i, C l, B i, K)$ liberados pelos cimentos foram detectados nos extratos. Entretanto, as células não apresentaram alterações significativas em sua morfologia.
EndoBinder e MTA, não afetaram negativamente o metabolismo das células odontoblastóides, mostrando-se citocompativeis, independente do radiopacificador utilizado.

\section{Acknowledegements}

The authors would like to thank the "Laboratory of Structural Characterization - Materials Department" (LCE-DEMa - UFSCar/ São Carlos, SP, Brazil) and the "Chemical Institute of Araraquara" (IQ-UNESP/ Araraquara, SP, Brazil) for their technical contribution to the study. The authors also like thank the "Foundation for University Estadual Paulista Development" (FUNDUNESP - grants: 0024/021/13-PROPe-CDC and 002/2015-PROPe/Unesp), and the "National Council for Scientific and Technological Development" (CNPq - grants: 307696/2014-6 and 301029/2010-1) for the financial support.

\section{References}

1. Olsson $H$, Petersson $K$, Rohlin M. Formation of a hard tissue barrier after pulp capping in humans. A systematic review. Int Endod J 2006;39:429442.

2. Nair PNR, Duncan HF, Pitt Ford TR, Luder HU. Histological, ultrastructural and quantitative investigations on the response of healthy human pulps to experimental capping with mineral trioxide aggregate: a randomized controlled trial. Int Endod J 2008;41:128-150.

3. Leye Benoist F, Gaye Ndiaye F, Kane AW, Benoist HM, Farge P. Evaluation of mineral trioxide aggregate (MTA) versus calcium hydroxide cement (Dycal ${ }^{\circledR}$ ) in the formation of a dentine bridge: a randomised controlled trial. Int Dent J 2012;62:33-39.

4. Slompo C, Peres-Buzalaf C, Gasque KC, Damante CA, Ordinola-Zapata $\mathrm{R}$, Duarte MA, et al.. Experimental calcium silicate-based cement with and without zirconium oxide modulates fibroblasts viability. Braz Dent J 2015;26:587-591

5. Coaguila-Llerena $H$, Vaisberg $A$, Velásquez-Huamán Z. In vitro cytotoxicity evaluation of three root-end filling materials in human periodontal ligament fibroblasts. Braz Dent J 2016;27:187-191.

6. Camilleri J. The physical properties of accelerated Portland cement for endodontic use. Int Endod J 2008;41:151-157.

7. Ozdemir HO, Ozcelik B, Karabucak B, Cehreli ZC. Calcium ion diffusion from mineral trioxide aggregate through simulated root resorption defects. Dent Traumatol 2008;24:70-73.

8. Camilleri J. Hydration mechanisms of mineral trioxide aggregate. Int Endod J 2007;40:462-470.

9. Min KS, Park HJ, Lee SK, Park SH, Hong CU, Kim HW, et al.. Effect of mineral trioxide aggregate on dentin bridge formation and expression of dentin Sialoprotein and Heme 0xygenase- 1 in human dental pulp. J Endod 2008;34:666-670.

10. Cavicchi M, Gibbs L, Whittle BJ. Inhibition of inducible nitric oxide synthase in the human intestinal epithelial cell line, DLD-1, by the inducers of heme oxygenase 1, bismuth salts, heme, and nitric oxide donors. Gut 2000;47:771-778.

11. de Souza Costa CA, Hebling J, Scheffel DL, Soares DG, Basso FG, Ribeiro AP. Methods to evaluate and strategies to improve the biocompatibility of dental materials and operative techniques. Dent Mater 2014;30:769-784.

12. Porter ML, Bertó A, Primus $C M$, Watanabe I. Physical and chemical properties of new-generation endodontic materials. J Endod 2010;36:524-528.

13. Piconi $C$, Maccauro G. Zirconia as a ceramic biomaterial. Biomaterials 1999;20:1-25.

14. International Standards Organization: ISO 10993-12:2012 (E). Biological evaluation of medical devices - Part 5: Tests for in vitro cytotoxicity. 2nd ed. Géneve: ISO; 2012.

15. Mosmann T. Rapid colorimetric assay for cellular growth and survival: application to proliferation and cytotoxicity assays. J Immunol Methods 1983;65:55-63.

16. Turrioni AP, Basso FG, Montoro LA, Almeida L de F, Costa CA, Hebling J. Phototherapy up-regulates dentin matrix proteins expression and synthesis by stem cells from human-exfoliated deciduous teeth. J Dent 
2014:42:1292-1299

17. Pontes EC, Soares DG, Hebling J, Costa CA. Cytotoxicity of resin-based luting cements to pulp cells. Am J Dent 2014;27:237-244.

18. Tanomaru-Filho M, da Silva GF, Duarte MA, Gonçalves M, Tanomaru JM. Radiopacity evaluation of root-end filling materials by digitization of images. J Appl Oral Sci 2008;16:376-379.

19. Camilleri J. Evaluation of the physical properties of an endodontic Portland cement incorporating alternative radiopacifiers used as rootend filling material. Int Endod J 2010;43:231-240.

20. Aguilar FG, Garcia L da F, Rossetto HL, Pardini LC, Pires-de-Souza F de C. Radiopacity evaluation of calcium aluminate cement containing different radiopacifying agents. J Endod 2011;37:67-71.

21. Aguilar FG, Roberti Garcia LF, Panzeri Pires-de-Souza FC. Biocompatibility of new calcium aluminate cement (EndoBinder). J Endod 2012;38:367-371.

22. Garcia $L$ da F, Huck $C$, Menezes de Oliveira $L$, de Souza PP, Souza Costa CA. Biocompatibility of new calcium aluminate cement: tissue reaction and expression of inflammatory mediators and cytokines. J Endod 2014;40:2024-2029.

23. Dammaschke T, Gerth HUV, Zuchner H, Schafer E. Chemical and physical surface and bulk material characterization of white ProRoot MTA and two Portland cements. Dent Mater 2005;21:731-738.

24. Pires-de-Souza F de C, Moraes PC, Garcia L da F, Aguilar FG, Watanabe E. Evaluation of $\mathrm{pH}$, calcium ion release and antimicrobial activity of a new calcium aluminate cement. Braz Oral Res 2013;27:324-330.
25. Oliveira IR, Andrade TL, Parreira RM, Jacobovitz M, Pandolfelli VC. Characterization of calcium aluminate cement phases when in contact with simulated body fluid. Mater Res 2015;18:382-389.

26. Torabinejad M, Parirokh M. Mineral trioxide aggregate: a comprehensive literature review--Part III: Clinical applications, drawbacks, and mechanism of action. J Endod 2010;36:400-413.

27. Garcia LFR, Aguilar FG, Sabino MG, Rossetto HL, Pires-de-Souza FCP. Mechanical and microstructural characterization of new calcium aluminate cement (EndoBinder). Adv Appl Ceram 2011;110:469-475.

28. Garcia L da F, Chinelatti MA, Rossetto HL, Pires-de-Souza F de C. Solubility and disintegration of new calcium aluminate cement (EndoBinder) containing different radiopacifying agents. J Endod 2014;40:261-265.

29. ANSI/ADA. Specification $N^{\circ} .57$ Endodontic sealing material. Chicago, IL: ANSI/ADA, 2000 (Reaffirmed 2006).

30. Torabinejad M, Parirokh M. Mineral trioxide aggregate: a comprehensive literature review--part II: leakage and biocompatibility investigations. J Endod 2010;36:190-202.
Received May 9, 2016 Accepted November 9, 2016 